University of Nebraska - Lincoln

DigitalCommons@University of Nebraska - Lincoln

Textile Society of America Symposium

Proceedings

Textile Society of America

2020

\title{
Intertwining the past and the present through textiles, experiences in the communities, a vision from Peru
}

Rommel Angeles Falcón

Ministry of Culture, Republic of Perú, rommelangel2@hotmail.com

Follow this and additional works at: https://digitalcommons.unl.edu/tsaconf

Part of the Art and Materials Conservation Commons, Art Practice Commons, Fashion Design Commons, Fiber, Textile, and Weaving Arts Commons, Fine Arts Commons, and the Museum Studies Commons

Angeles Falcón, Rommel, "Intertwining the past and the present through textiles, experiences in the communities, a vision from Peru" (2020). Textile Society of America Symposium Proceedings. 1137. https://digitalcommons.unl.edu/tsaconf/1137

This Article is brought to you for free and open access by the Textile Society of America at DigitalCommons@University of Nebraska - Lincoln. It has been accepted for inclusion in Textile Society of America Symposium Proceedings by an authorized administrator of DigitalCommons@University of Nebraska - Lincoln. 
Published in Hidden Stories/Human Lives: Proceedings of the Textile Society of America 17th Biennial Symposium, October 15-17, 2020. https://digitalcommons.unl.edu/tsaconf/ Copyright @ 2020 Rommel Angeles Falcón doi: $10.32873 /$ unl.dc.tsasp.0080

\title{
Intertwining the past and the present through textiles, experiences in the communities, a vision from Peru
}

\author{
Rommel Angeles Falcón
}

\section{$\underline{\text { Introduction }}$}

Textile making is a hallmark of the societies that occupied the Andes, reflected in the varied roles that these had based on their characteristics as objects for clothing, funeral offerings, vehicles for the transmission of ideas, symbols of status, or ethnic and chronological differentiation (Figure 1). Textile making is a traditional activity of great antiquity (at least 5000 years) which evolves and continues to this day.

Textile traditions exist to this day in communities on the south coast, the southern highlands and the altiplano, the central highlands, the northern highlands and the north coast. In the central and south-central Andes, weaving traditions based on reeds and bast fibers both on the coast and in some communities in the mountains, demonstrate a continuing tradition. Likewise, Amazonian societies also preserve techniques of textile construction and decoration that preserve aspects of their deep meanings. 


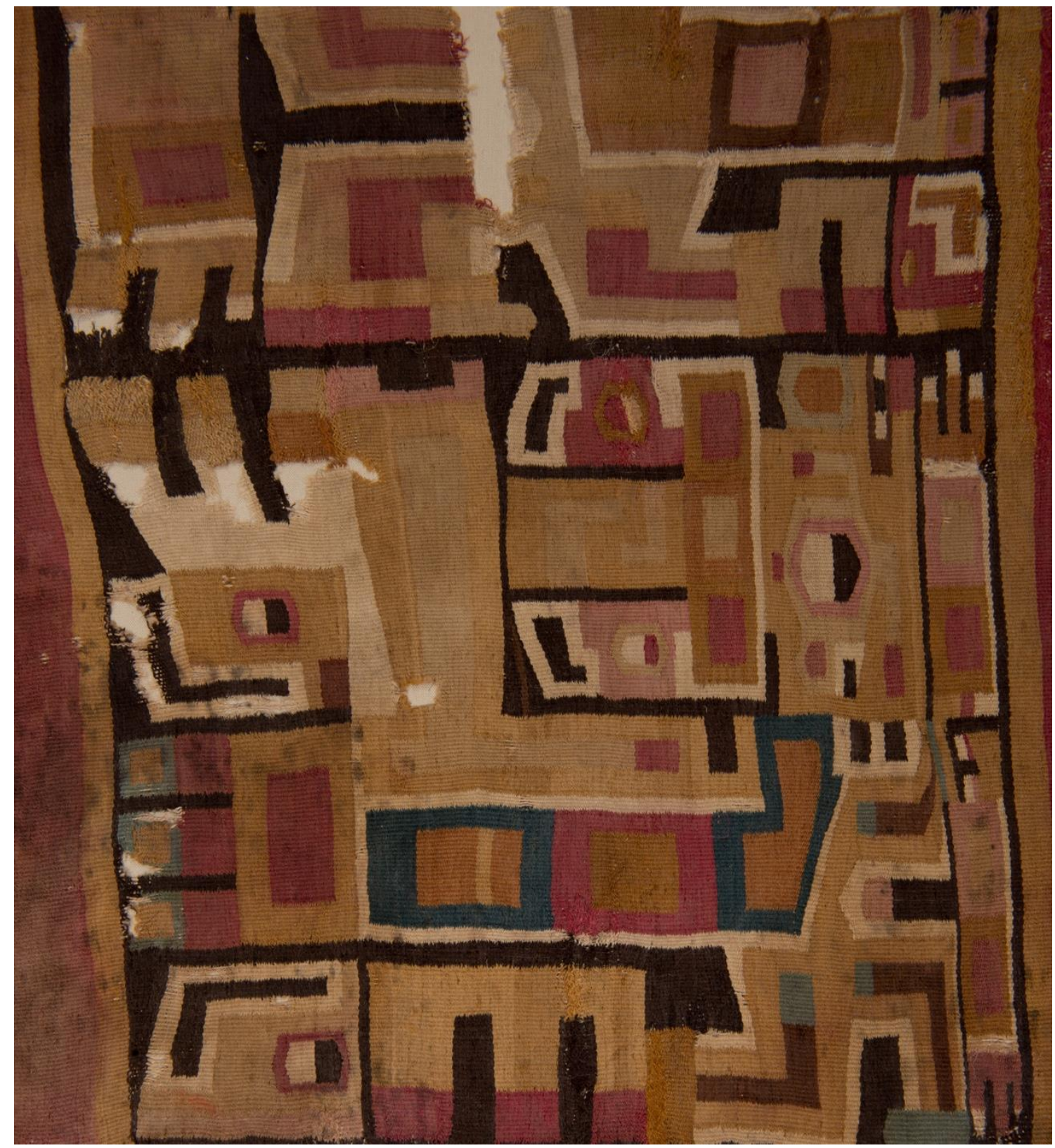

Figure 1. Detail, eccentric tapestry in the Wari style (700-900 d.C.) Huaca Malena. Photo R. Angeles.

This essay seeks to identify the processes by which pre-Hispanic textiles have formed part of a symbolic language for Peruvian cultural identity from the beginning of the 20th century to the present time. In this process, politics, economics, academia, artists and the artisans all play a part. In other words: how this pre-Hispanic heritage revealed in forms and designs was incorporated into the national identity. However, we consider it important to review the preexisting conditions that made textile traditions and their meanings invisible. 


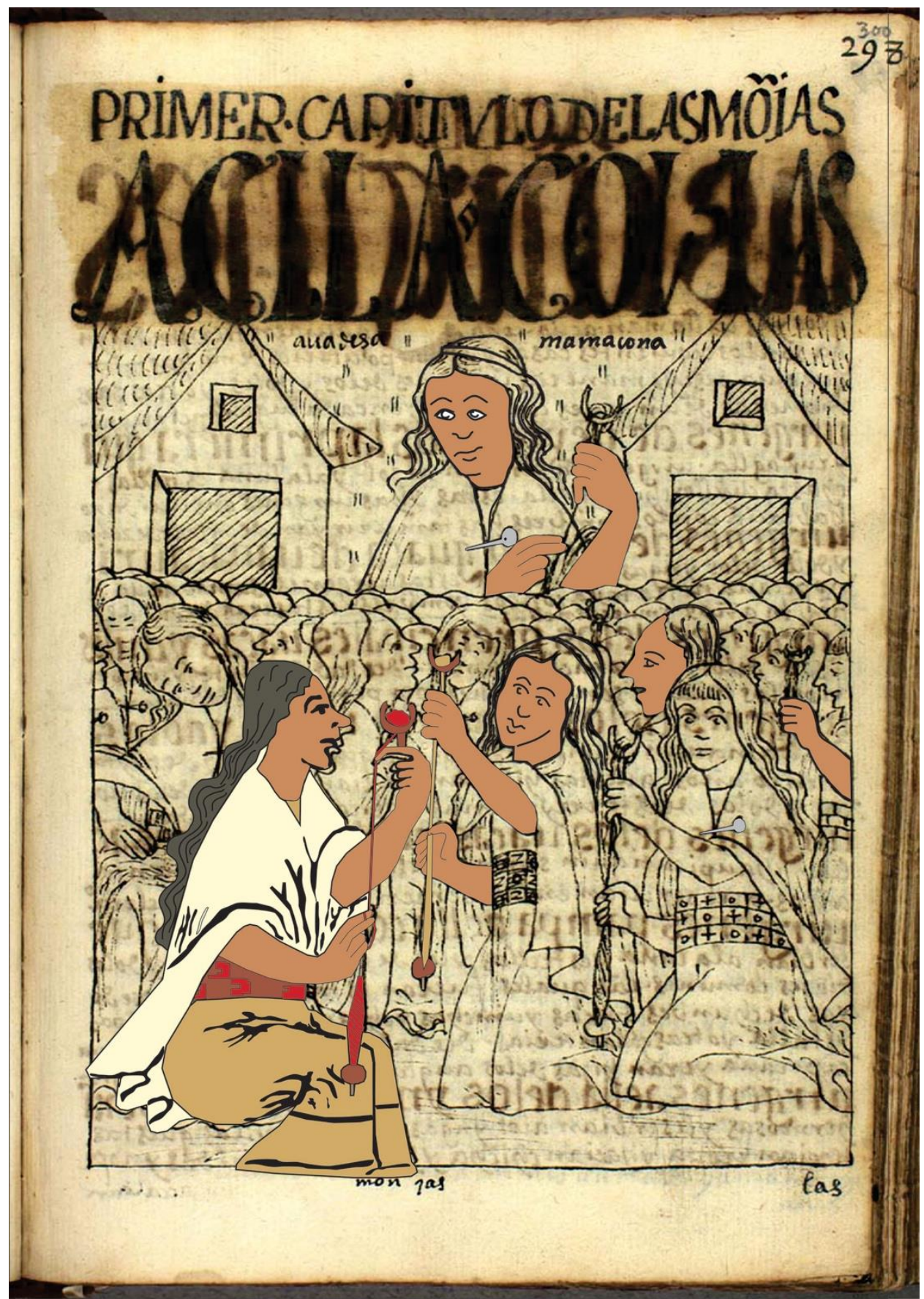

Figure 2. First chapter of the acllacuna nuns. Redrawn from Guaman Poma de Ayala (c. 1615)

\section{The Colonial period}

Upon the arrival of the Spaniards in the 16th century, they were impressed by the fine and varied clothing of the Incas and the other populations that occupied the territory of Tawantinsuyu, as well as the existence of specialized producers dedicated to these labors in service to the empire. A type of specialist women called acllacuna occupied important enclosures called acllawasi whose functions included the creation of textiles for ceremonies and rituals as well as activities 
for the priesthood that were described by the first chroniclers (Figure 2). Additionally, there were men dedicated to making fine fabrics, called cumbi camayoc.

Spanish chroniclers describe with great precision the role of textiles in the Andes, permitting John Murra to accurately define the function of textiles in the Inca period. ${ }^{1}$

At the end of the 16th century, the extirpation of idolatries began and among the norms stipulated by Church officials are denunciations and restrictions of the use of textiles in the worship of Andean deities, as well as the use of ceremonial clothing in festivals and celebrations, considering these as idolatrous activities.

Even before this, Andean clothing underwent notable changes as it adapted many elements of Hispanic clothing: pants, doublets, shirts, earrings, shoes, underwear, and skirts. Women began to wear European skirts and only preserved ornamental waist bands and probably hair bands. Men begin to wear pants.

In the early seventeenth century, Felipe Guaman Poma de Ayala ${ }^{2}$ depicts in his drawings the varied clothing of the Incas and the communities that formed part of the empire as well as the diverse ways of making fabrics. Some images show the clothing of the Inca elite, the acllacuna and the various groups differentiated by their clothing and their headdresses. Additionally, the images of indigenous people are observed with some elements of the Spanish wardrobe. It is evident that Spaniards are not observed in indigenous clothing.

Viceregal art promotes Christian religious representations and the elites of the Spanish government through paintings. Textile art is present in tapestries used in churches and convents with religious and European designs but made with the skillful indigenous hand. The Cuzco elites who sought to validate their power used ceremonial dress and symbols of power that associated them with the former Inca emperors during public ceremonies carried out in Cusco. ${ }^{3}$

At the end of the 18th century, the uprising of Túpac Amaru took place and when it was defeated, among other things, the indigenous elites were prohibited from wearing pre-Hispanic types of clothing or pre-Hispanic icons ornamenting their attire.

\footnotetext{
${ }^{1}$ John V. Murra, "Cloth and its functions in the Inca State.” American Anthropologist Vol. 64 No. 4 (August 1962), $710-728$.

${ }^{2}$ Felipe Guaman Poma de Ayala, El primer nueva corónica y buen gobierno (1615/1616) (København, Det Kongelige Bibliotek, GKS $22324^{\circ}$ ) http://www5.kb.dk/permalink/2006/poma/info/en/frontpage.htm

${ }^{3}$ Carolyn Sue Dean, Inka bodies and the body of Christ: Corpus Christi in colonial Cusco. (Durham: Duke University Press, 1999).
} 
In the north of Peru, Bishop Martínez de Compañón carried out extensive documentation ${ }^{4}$ of the customs of the northern region of Peru in the $18^{\text {th }}$ century, in which you can see watercolors of textile practices made by indigenous people, drawings of fabrics as well as a scene corresponding to the burial of a nobleman with pre-Hispanic clothing. It is interesting to note that many of the personages represented are already dressed with a strong European influence, but the indigenous people of the Amazon retain their traditional garments. Although in Guaman Poma de Ayala's drawings you can see traditional Andean waist looms and vertical looms, Martinez de Compañon's document depicts the European pedal loom that continues to be used in the Andes to this day, especially by men.

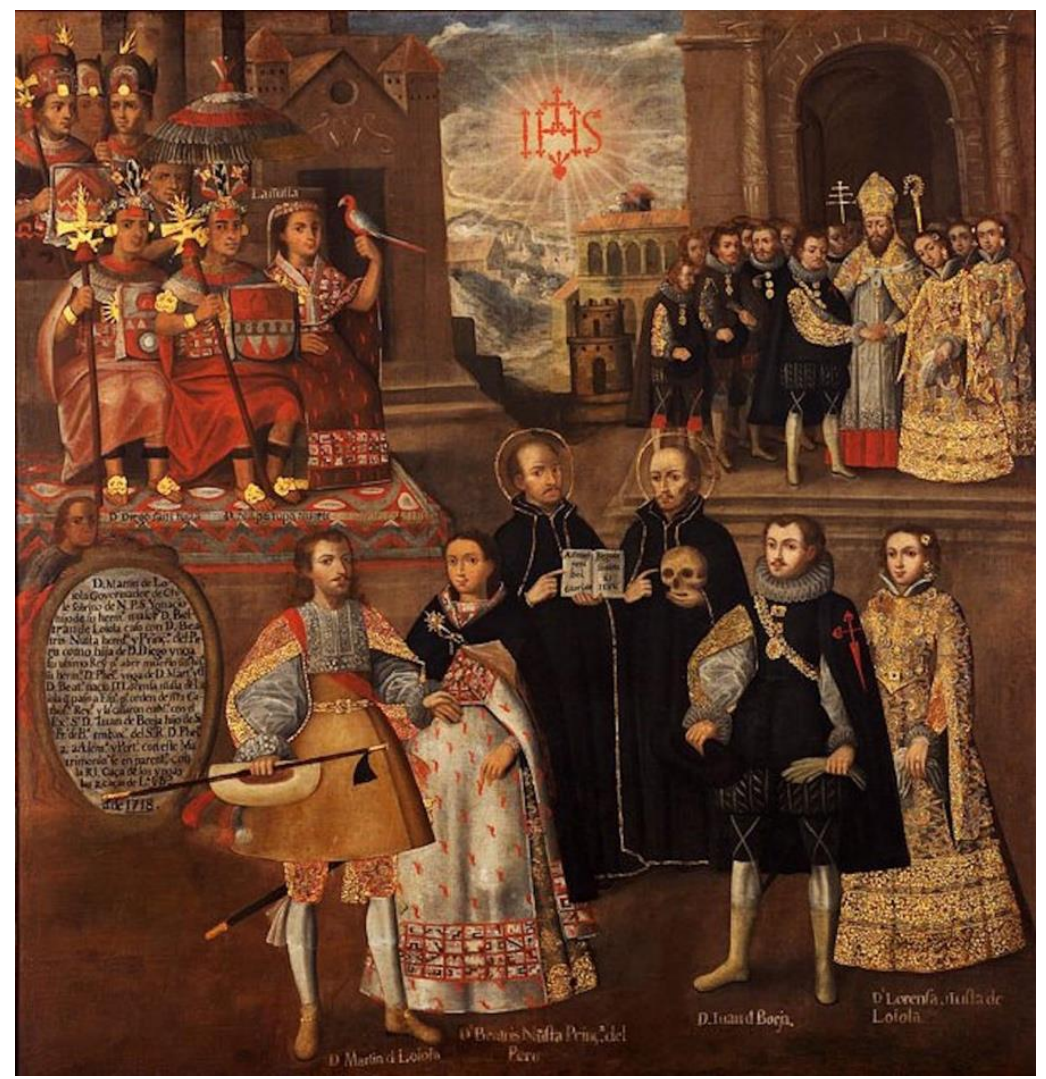

Figure 3. Cusco School painting "Marriages of Martín de Loyola with Beatriz Nusta and of Juan de Borja with Lorenza Nusta de Loyola" in the La Compañia church, Cusco. Public domain, accessed at:

https://upload.wikimedia.org/wikipedia/commons/8/81/The_Marriage_of_Captain_Martin_de_Loyola_to_Beatriz_\%C3\%91usta. ipg

In the 18th century, the Cuzco School painting "Marriages of Martín de Loyola with Beatriz Nusta and of Juan de Borja with Lorenza Nusta de Loyola" from the year 1718 stands out, which shows two marriages that united the Inca royal descendants with that of two of the patriarchs of the Society of Jesus. The first wedding, carried out in 1572, united the Spanish captain Martín

\footnotetext{
${ }^{4}$ Balthazar Jaime Martinez Compañon, (ms. circa 1782-1785) Codex Martínez Compañón in the Royal Library, Madrid. Also published as: Trujillo del Perú a fines del siglo XVIII: dibujos y acuarelas que mandó hacer el Obispo D. Baltasar Jaime Martínez Compañón (Madrid: C. Bermejo, Taller Hauser y Menet, 1936).
} 
García de Loyola - great-nephew of San Ignacio and defeater of Túpac Amaru I, the last rebel Inca, whom a Jesuit catechist converted before his execution - with the $\tilde{n} u s t a$ or imperial princess Beatriz Clara Coya, daughter of Sayri Túpac, brother of the defeated monarch (Figure 3). The second marriage - celebrated in Madrid in 1611 - corresponds to that of their mestizo daughter, Ana María Lorenza de Loyola Coya, with Juan Enríquez de Borja, grandson of San Francisco de Borja. There were almost forty years between one event and another, however they are represented simultaneously and in the same space, with evident propaganda intentions. In other words, the clothing of the Inca family constitutes the main attribute of indigenous power to which Spanish power is added, in an attempt to present a natural continuity in these events.

Elena Phipps has explained and presented a series of colonial textiles where tapestries stand out both in male tunics and parts of female clothing, predominantly created in warp face techniques. ${ }^{5}$

Not much information is known about the textile tradition or the role of weavers at the end of the Colonial period or during independence. It is evident that these are strongly preserved in everyday clothing but they are especially used in religious or political ceremonies. In these contexts, the festive clothing that expresses local and regional traditions stands out.

Pre-Hispanic clothing endures in a modified way: the current poncho forms derive from the preHispanic uncu tunic, the lliclla woman's mantle remains and the woman's decorative waist band is a fundamental element that stores information of high symbolic value. With independence in the nineteenth century, a search for identity as a nation was born, however this was founded in an idea of continuity.

\section{The beginning of the 20th century}

In the 20th century, within the framework of reinforcing cultural identity 100 years after the independence of Peru, a series of movements arose aimed at promoting the rich Peruvian archaeological heritage from various perspectives. The works of Max Uhle and Julio C. Tello made it possible to see the historical depth of Peruvian cultures. This was reinforced by the discovery of Paracas in 1925 as well as the creation of the Museum of Peruvian Archeology (later the National Museum of Archaeology) during the government of Augusto B. Leguía.

In this context, in the 1930s the artist Elena Izcue was recreating pre-Hispanic designs on painted fabrics and watercolors, creating artistic works. ${ }^{6}$ Her work in the decorative arts played a decisive role in the discovery of pre-Columbian art at the beginning of the 20th century. Izcue's work was inspired by great archaeological discoveries in Peru and their dissemination, combined with emergent ideologies inspired by concepts of indigenous roots, added to the initiative by

\footnotetext{
${ }^{5}$ Elena Phipps, Johanna Hecht and Cristina Esteras, The Colonial Andes: Tapestries and Silverwork, 1530-1830, (The Metropolitan Museum of Art and Yale University Press, 2004).

${ }^{6}$ Natalia Majluf, Elena Izcue: Lima-Paris Años 30, (Paris: Musée du Quai Branly/Flammarion, 2000).
} 
President Augusto B. Leguía to build a national identity with pre-Hispanic referents that invoked indigenous art. It was used as propaganda at the time the captive provinces of Tacna and Arica were under occupation after the war with Chile.

In the 1950s, pre-Hispanic textiles were also an inspiration for modern architecture, as exemplified by the structural and surface decoration of emblematic buildings such as the Ministry of Education of Lima, part of an architectural identity inspired by pre-Hispanic forms. This practice has antecedents from the 1920s, in both the architcture of the Museum of Peruvian Archaeology (today the Museum of Peruvian Culture), inspired by the architecture of Tiwanaku, and the private home of archaeologist Julio C. Tello, inspired by Moche ceramics.

In the 1970s, at the time of the Revolutionary Government of the Armed Forces, ${ }^{7}$ cultural identity was promoted from the State as a way to vindicate the great past and improve the conditions of the populations in general. The creation of the National Institute of Culture was an important milestone as well as the national craft award to Joaquín Lopez Antay ${ }^{8}$ considering his work at the art level, this stage allowed the visibility of a significant number of artisans, including the traditional weavers whose art began to be revalued and who in some cases began to use pre-Hispanic iconography as a source of inspiration and cultural continuity.

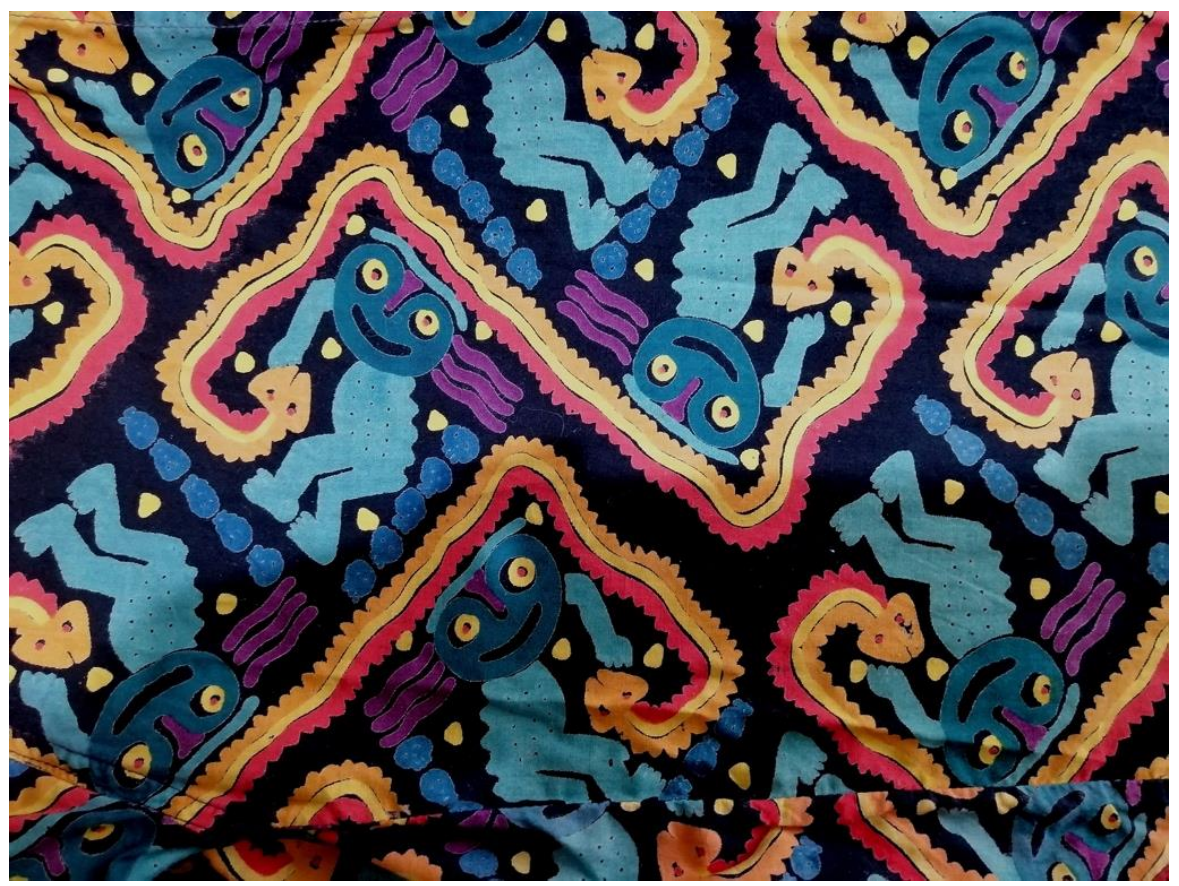

Figure 4. Detail of textile printed with Paracas designs, Silvania Prints. Collection and photo R. Angeles.

\footnotetext{
${ }^{7}$ Following a coup in 1968, the Gobierno Revolucionario de las Fuerzas Armadas, led by General Juan Velazco Alvarado, instituted a form of socialist rule involving a major agrarian reform and nationalization of petroleum and mining industries. Military rule lasted through the 1970s.

${ }^{8}$ Joaquin Lopez Antay adapted a traditional religious miniature, the Cajón de San Marcos, to develop a new art form, the Retablo Ayacuchano.
} 
An example of this is the work of Silvia Edzard-Hoffman Lawson (wife of the archaeologist Victor von Hagen) who founded the company Silvania Prints. Following Izcue's proposals, her textiles constituted a milestone in the reuse of pre-Hispanic designs for both clothing and home furnishings. In 1957 she opened stores in the center of Lima and in Cusco, serving the public until 2004 (Figure 4).

A proposal linked to the recovery of Peruvian cotton has been carried out since the late 1970s by James Vreeland on the north coast, assessing the natural hues of native cotton varieties that were in the process of disappearance. ${ }^{9}$

In the 1980s, loom artists from the Ayacucho region such as the Oncebay family or Máximo Laura ${ }^{10}$ constitute true icons. ${ }^{11}$ Based on an extraordinary ability for weaving inherited from their Wari ancestors, they have created true contemporary works of art inspired by Wari textiles (AD 700-950), works recognized worldwide. They constitute true examples of the new cumbicamayos, master weavers of Peru. To these achievements we can add the recent proposals of the Sulca family, who turn to the archaeologists of Ayacucho for inspiration to reproduce Wari style fabrics.

On the other hand, since the 1980s, in the town of Pampa Libre, in the Chancay valley 30 kilometers north of Lima, women have learned to reproduce pre-Hispanic fabrics for an informal market. Unfortunately, they use pre-Hispanic threads and fabrics, affecting the archaeological heritage. They continue to be involved in this activity today. Over those years, recreations of "Chancay" dolls have been made for sale in various markets, unfortunately using cut up preHispanic fabrics.

The 1990s

In the 1990s, Peru experienced significant changes at the political level that produced massive displacement of populations from the mountains to the coast, increasing the formation of marginal settlements with poor infrastructure, as is the case in the capital city of Lima. These families were losing their weaving skills and, in some cases, they occupied archaeological zones in the new territories with which they did not feel a relationship.

At the beginning of the year 2000, Jenny Figari from the Yachaywasi Conservation Institute ${ }^{12}$ coordinated a project at the Cajamarquilla archaeological site in Lima that involved women who lived in marginal settlements around the site. She promoted the recovery of warp-dominant techniques in camelid fiber as a community development project. This experience was developed for 8 years, promoting the recovery of traditional textile techniques, even if these were not

\footnotetext{
${ }^{9}$ James M. Vreeland, “The Revival of Colored Cotton,” Scientific American Vol. 280 No. 4 (1999), $112-118$.

${ }^{10}$ Laura Máximo: https://maximolaura.com/about-maximo-laura/

${ }^{11}$ Máximo, Laura, Tapiz de Ayacucho, (Lima: Ministerio de Cultura, 2015).

${ }^{12}$ Instituto Superior de Conservación y Restauración Yachaywasi. https://www.yachaywasi.org/quienes-somos/
} 
related to the archaeological findings. The effort, however, did not obtain state support and ended about 10 years after it began.

The museums of the 20th and 21st centuries begin a different look at their role within society and question the way they should relate to their environment. At the same time, initiatives in teaching and learning textile techniques arose from diverse interests, in many cases based on the experiences of weavers from the mountains, the textile traditions of the coast and the remarkable interest of young people in learning. Resist dyeing, warp face and tapestry techniques have been the most developed. Although iconographic models from archaeological excavations have not been used, a social enterprise has developed.

One interesting experience is that developed by the Túcume Museum of Lambayeque, in which, from the 1990s to the present day, nearby residents practice the cultivation of native cotton and preserve artisanal weaving practices. The Tucume museum has become a focal point to involve the community with its own heritage and provides the space for the practice of loom weaving and, at the same time, the creation of products [designed] for daily use to sell to tourists. In other words, the cultivation of native cotton is maintained, weaving practices have continued but the finished forms of these products have acquired new uses destined to become souvenirs for visitors. It should be noted that visitors do not usually buy complete cloths, with rare exceptions.

The Tucume museum worked with AXIS Arte, a group from the Pontificia Universidad Católica del Perú ${ }^{13}$ that, working with pre-Hispanic designs, proposes that they be applied on products for sale to the public at this museum. For example, archaeological excavations in Túcume revealed a clay frieze with a mythical scene where birds and characters on rafts stand out (Figure 5a).

a)

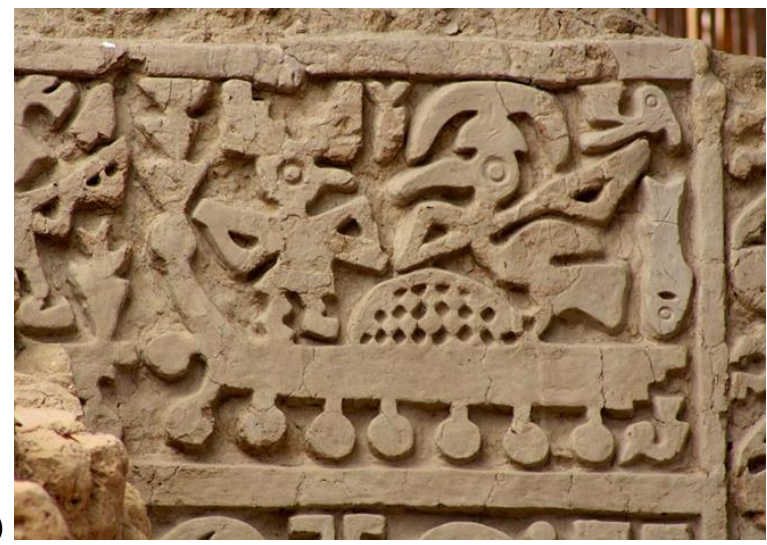

Figure 5. a) Clay frieze with a maritime fishing scene, 14th-15th century. Túcume, Lambayeque. b) Design of the maritime fishing scene reproduced on cloth: resist dye technique. Julian Bravo, Túcume. Photos R. Angeles.

This iconography inspired its recreation in textiles decorated using resist dyeing, in which several artisans from the area such as Julián Bravo excel (Figure 5b). They now have their own

\footnotetext{
${ }^{13}$ Axis Arte: https://departamento.pucp.edu.pe/arte-y-diseno/grupos_investigacion/grupo-axis-arte/
} 
workshops and teach courses and workshops in other locations. The mythical scene therefore has been transformed into a design that strengthens the identification of the community with its past. Túcume artisans have been incorporated into the Ruraq Maqi fairs organized by the Ministry of Culture (Figure 6). ${ }^{14}$

On the south coast, it is important to highlight the contribution of Rosa Choque, an artisan from the Carumas community in Moquegua. She works at the El Algarrobal Museum ${ }^{15}$ in Ilo directed by Sonia Guillén, bioanthropologist and former National Director of Museums for Peru's Ministry of Culture. Rosa's experience as a loom weaver has allowed her to restore warp face textiles as well as faithfully reproduce the quality and designs of Chiribaya fabrics. Rosa Choque's experience starts in this case from her contact with a museum and its collections; however, she does not produce products suitable for the market, but rather preserves tradition in the purest way, becoming an example that transcends chronological time.
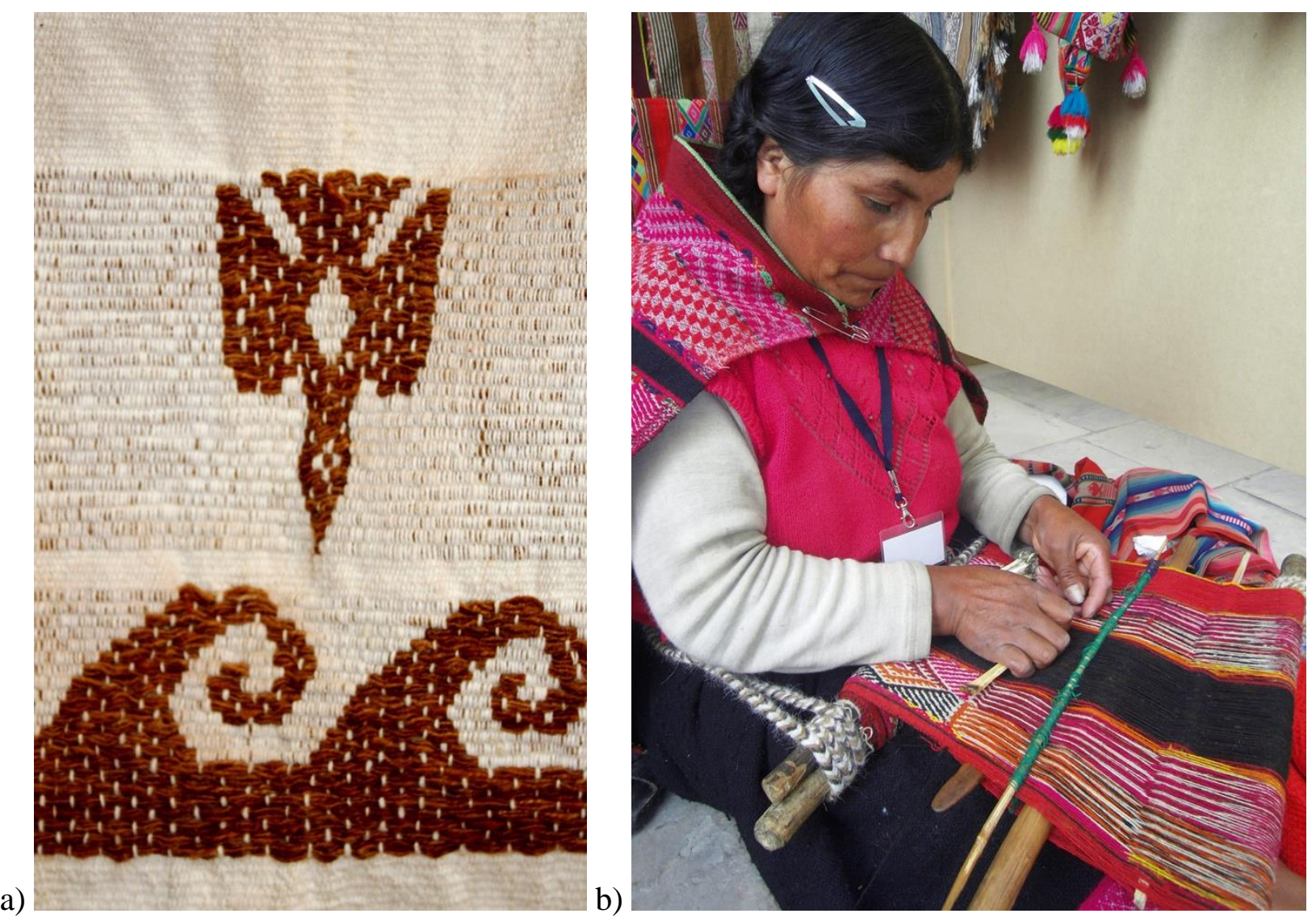

Figure 6. a) Traditional weave in native cotton produced by the Túcume artisans of Lambayeque, that reproduces a prehispanic design of waves and a marine bird in a technique and style characteristic of Lambayeque in the 11th - 15th century. b) Cusco artisan weaving on a backstrap loom. Craft fair Ruraq Maki (Handmade) at Peru's Ministry of Culture. Photos R. Angeles.

\footnotetext{
${ }^{14}$ Ruraq Maki, Tucume artisans page: https://www.ruraqmaki.pe/asociacion-de-artesanos-de-tucume/

${ }^{15}$ El Algarrobal: Museo Chiribaya and Centro Mallqui. https://www.centromallqui.pe/ilo/museochiribaya.html
} 
In recent years in Peru, a series of independent efforts have begun to be developed by groups, which, taking the pre-Hispanic textile heritage as a reference, have begun to replicate and teach about ancient techniques.

Pre-Hispanic art from the academy

Carmen García is a professor of Art and Design at PUCP who has developed a strategic alliance with museums and archaeological projects aimed at Art and Design students to develop innovative proposals from pre-Hispanic iconography.

Dorothee Rago, a North American fine artist, has contributed an artistic vision by capturing in her watercolors artifacts from ceramics to textiles, representing their original colors and reproducing the designs of Chiribaya, Huarmey and Paracas fabrics, among others. ${ }^{16}$

a)

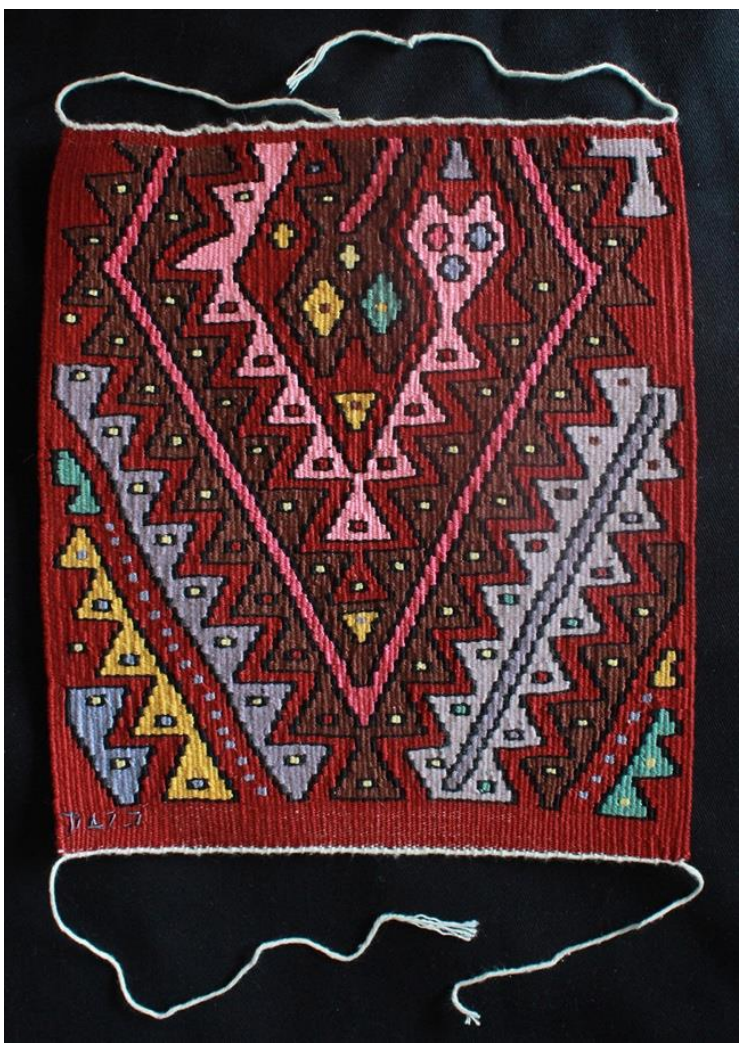

b)

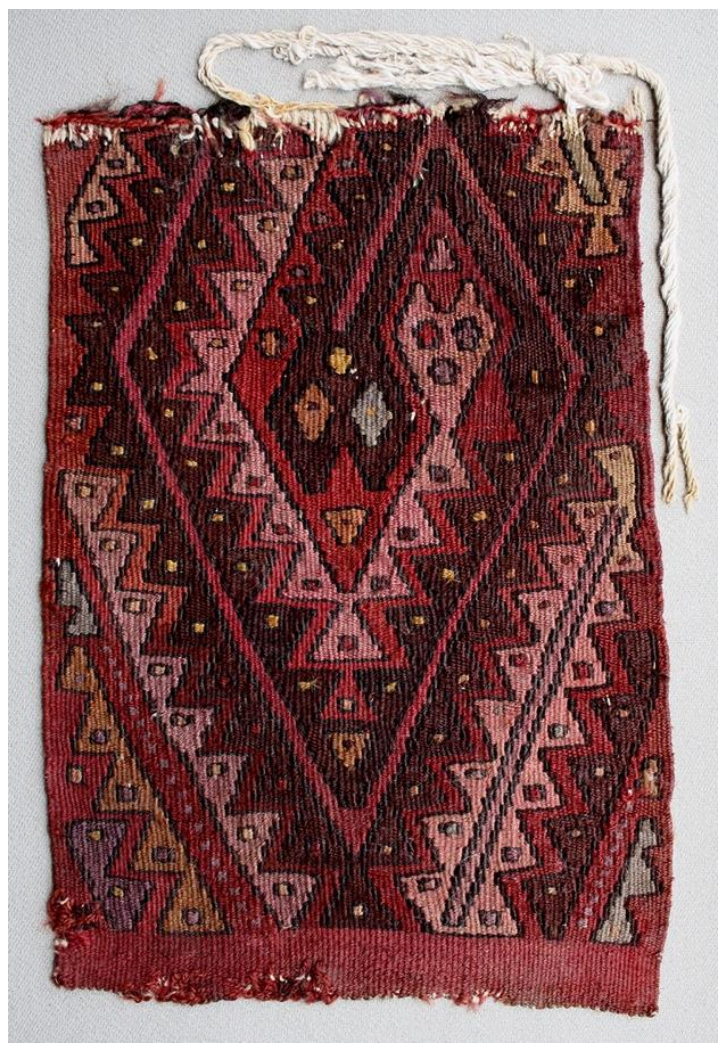

Figure 7. a) Reproduction in tapestry technique, created by the arisan Esteban Nazario based on a photograph of the Huaca Malena textile. $b$ ) Textile in tapestry technique, provenience Huaca Malena, Asia valley (10th - 11th century) that was reproduced by the artisan Esteban Nazario. Collection Huaca Malena Museum. Photos R. Angeles.

Andrés Yntusca is an artisan native to Chancay with an extraordinary ability to reproduce preHispanic techniques of textiles from the coast. A teacher by profession, Andrés Yntusca promotes the reproduction of pre-Hispanic techniques, based at the San Marcos University

\footnotetext{
${ }^{16}$ Dorothee Rivka Rago, Mensajes hilados del pasado: Ilustración de tejidos Moche y Moche-Wari, (Lima: selfpublished, 2017).
} 
Archeology Museum. He teaches craft workshops on textile techniques, generating a significant number of artisans who discover pre-Hispanic fabrics. Tapestries of Huaca Malena, Armatambo and Chancay have been part of these experiences, including analysis of the technical characteristics of the fabrics and their reproduction by means of a rather peculiar loom.

Esteban Nazario from the city of Huacho in the north of Lima is a skilled craftsman who reproduces pre-Hispanic techniques of tapestry, gauze, double cloth and others. Based on the observation of pre-Hispanic fabrics from his region, he has created workshops and disseminates his work through his web page, ${ }^{17}$ having participated in many exhibitions. He uses cotton fiber and camelid fiber (alpaca), especially reproducing the techniques of the Chancay culture of which he is considered a descendant (Figure 7).

In the case of Nilda Callañaupa and the Center for Traditional Textiles of Cusco (CTTC),$^{18}$ this organization forms part of a large network of artisan collectives from Cusco. They have begun to define some lines based on the techniques and iconography of pre-Hispanic textiles, including Paracas and early Nasca.

Added to this is the silent work of Yuki Seo, a Japanese textile conservator who has been working on the recovery of pre-Hispanic techniques by sharing her experiences with Japanese artisans and conducting various courses and workshops that are the subject of a paper given at this event.

A very important case is Arturo Nery, professor at the José María Arguedas school in the Surco district of Lima, who teaches music and art through the reproduction of pre-Hispanic textile techniques, involving more than 500 young people working in the classroom on the senses, visual aesthetics, color, fine motor skills and understanding of pre-Hispanic geometry. He considers that their critical appreciation of pre-Hispanic art changes when they observe a textile, that they better understand and develop new neural networks. His own Andean origins reinforce his proposal.

The Michell Alpaca Group, a yarn and textile company, promotes the production of fine art textiles by master craftsmen through competitions. Many of the works are inspired by preHispanic fabrics.

The Sustainable Preservation Initiative (SPI), founded by Larry Coben, promotes the development of communities around archaeological sites through the reproduction of archaeological objects. There is funding for their training, organization, and strategic alliances are sought with museums for the exhibition and sales of their products. These activities are

\footnotetext{
${ }^{17}$ Esteban Nazario: https://www.instagram.com/esteban.nazario/?hl=en

${ }^{18}$ Centro de Textiles Tradicionales de Cusco, English: https://www.textilescusco.org/
} 
carried out in Pachacamac, supporting SISAN artisans (Figure 8) as well as in Huaca Chotuna Chornancap.

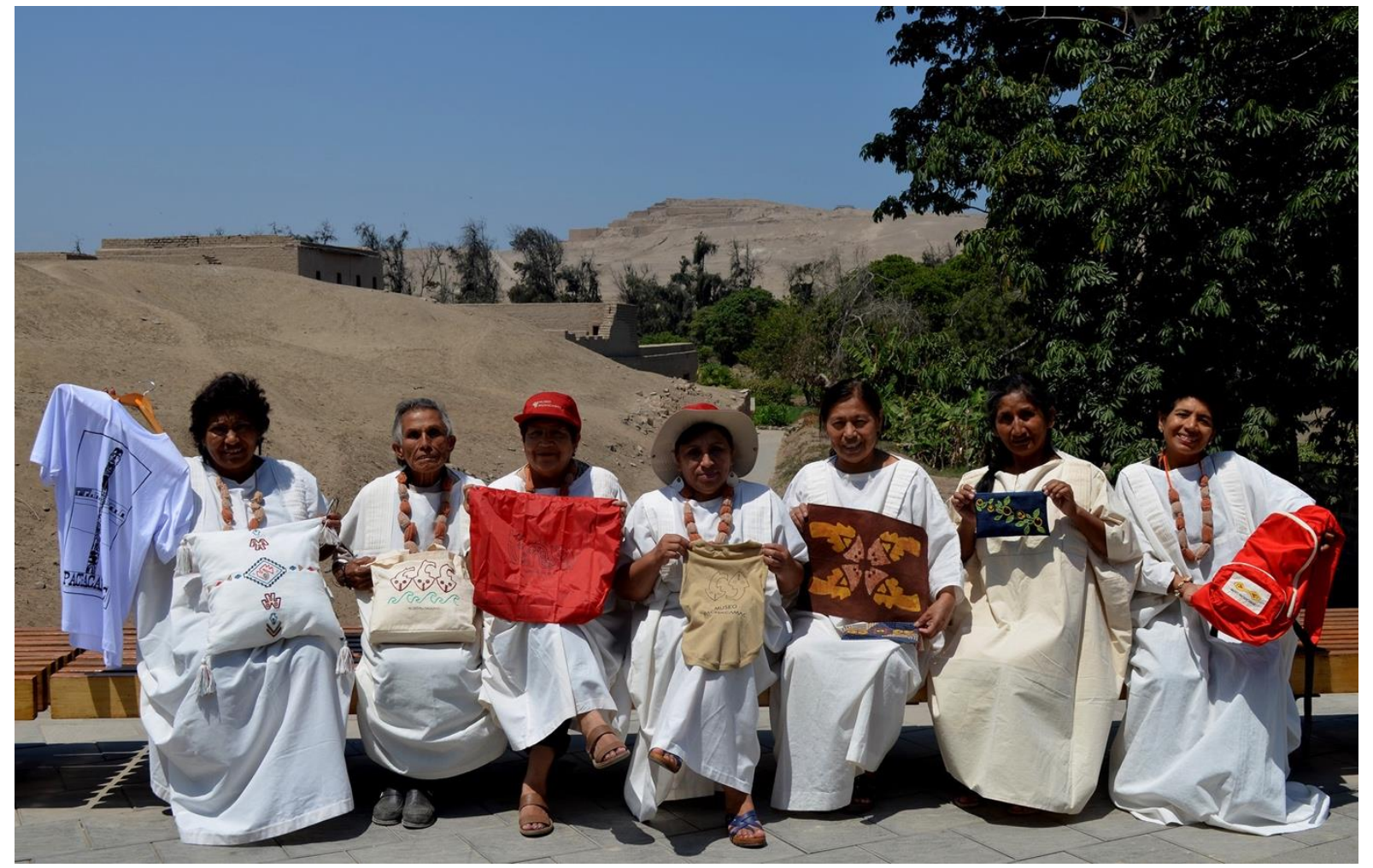

Figure 8. Artisans of the SISAN association of the Pachacamac Museum show their work, inspired by the iconography of textiles from the sanctuary of Pachacamac. Photo R. Angeles.

Since 2014, the Pachacamac Museum that manages the archaeological sanctuary of Pachacamac has a Management Plan approved on the ministerial level. This plan includes a commitment to the community development of the environment. In this framework, 50 women who live in the areas with fewer resources were invited to participate so that following workshops they could produce artisan products based on the iconography of the Pachacamac sanctuary (Figure 9).

At present they have been formalized into an association called SISAN (meaning to flourish) that produce embroidered or dyed fabrics for sale in the museum shop. In this case, the museum becomes an articulating entity between the heritage it preserves and the communities establishing sales opportunities for visitors through the museum shop. The artisans have been trained by various institutions and are currently receiving support from the LATAM airline company to recycle their flight uniforms.

The Pachacamac Museum store also exhibits and sells artisan products from Huaca Chotuna Chornancap, Puno and Ayacucho, taking advantage of the public it receives. 


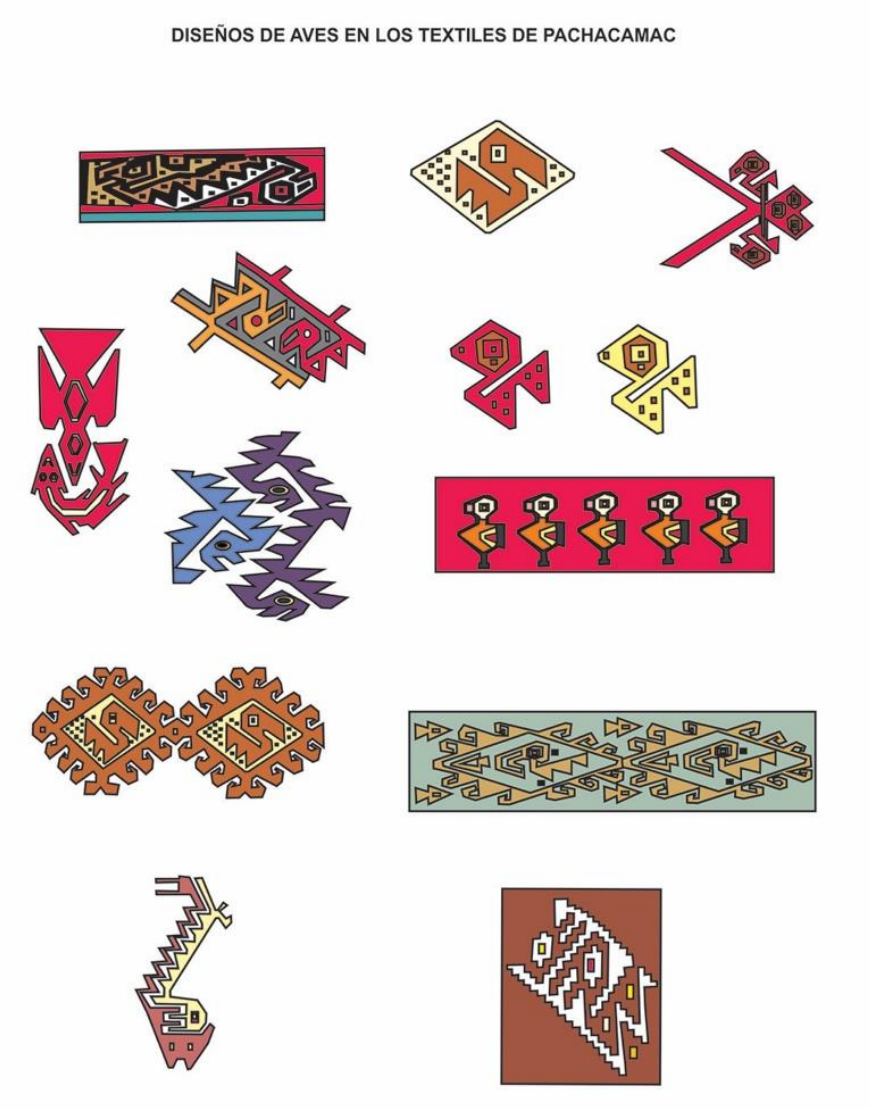

Figure 9. Iconography of "Ychma" designs characteristic of the regional texile tradition, which serve as inspiration for the artisans of the SISAN Association of the Pachacamac Museum. Drawing by R. Angeles.

\section{Conclusions}

The initiatives of the last 30 years, mentioned here, are all related to proposals to strengthen the relationship between archaeological heritage and the societies of the present, seeking to articulate mechanisms to improve the economies of the populations living around archaeological sites and museums or related to them, based on recovering traditional techniques, on ancestral imagery, and on the search for improvement in the living conditions of the communities.

The dissemination of archaeological heritage and the initiatives of some museums that seek to bring together surrounding communities that do not necessarily identify with said heritage, try to discover a cultural identity based on designs that generally are not understood ideologically, but rather that aesthetically are of great interest. We believe that it is the basis of a re-learning of ancient traditions, making visible that the skills to create and develop a craft are still present and that, by encouraging these skills, they can be reborn within a new urban and social context.

Although the State has not articulated these initiatives efficiently, with the exception of the yearly competition and craft show Yuraq Maki, we believe that the examples of Túcume or Pachacamac can become models that in the future can serve to demonstrate these possibilities. 
We seek to strengthen these artisan collectives, to organize them and that the State, through its museums, can provide spaces for them to develop their skills and allow the sale of their products.

In times of COVID, these groups make masks with pre-Hispanic designs.

This process of immigration from the mountains to the coast, which involved so many women with weaving skills, was not properly engaged to create an opportunity to recognize and foster these skills, and little by little these skills have been lost or were displaced by new jobs necessary for daily life.

These new experiences, however, contain an essential gap, since they fail to recover the original meaning of weaving in the Andean world where weaving is a language and a weaving is a being that has life within the communities that gave rise to it. 
Bibliography

Compañon, Balthazar Jaime Martinez, Codex Martínez Compañón, ca. 1782-1785, Trujillo del Perú a fines del siglo XVIII: dibujos y acuarelas que mandó hacer el Obispo D. Baltasar Jaime Martínez Compañón, Madrid: C. Bermejo, Taller Hauser y Menet, 1936.

Dean, Carolyn Sue, Inka bodies and the body of Christ: Corpus Christi in colonial Cusco, Durham: Duke University Press, 1999.

Guaman Poma de Ayala, Felipe, El primer nueva corónica y buen gobierno (1615/1616), Det Kongelige Bibliotek, http://www5.kb.dk/permalink/2006/poma/info/en/frontpage.htm.

Majluf, Natalia, Elena Izcue: Lima-Paris Años 30, Paris: Musée du Quai Branly/Flammarion, 2000.

Máximo, Laura, Tapiz de Ayacucho, Lima: Ministerio de Cultura, 2015.

Murra, John V., "Cloth and its functions in the Inca State," American Anthropologist Vol. 64 No. 4 (August 1962), 710-728.

Phipps, Elena, Johanna Hecht and Cristina Esteras, The Colonial Andes: Tapestries and Silverwork, 1530-1830, New York: The Metropolitan Museum of Art and New Haven: Yale University Press, 2004.

Rago, Dorothee Rivka, Mensajes hilados del pasado: Ilustración de tejidos Moche y MocheWari, Lima: self-published, 2017.

Vreeland, James M., “The Revival of Colored Cotton," Scientific American Vol. 280 No. 4 (1999), 112-118. 